\title{
Correlating structural properties to sodium release of model solid lipoproteic colloids
}

3

4
Wan-Yuan $\mathrm{Kuo}^{\mathrm{a} *}$ and Youngsoo Lee ${ }^{\mathrm{a}}$

${ }^{a}$ Department of Food Science and Human Nutrition, University of Illinois at UrbanaChampaign, 382K, Agricultural Engineering and Sciences Building, 1304 W. Pennsylvania Ave., Urbana, IL 61801, USA

*Corresponding author email: wkuo7@illinois.edu

\section{Abstract}

Effect of structure on sodium release of model solid lipoproteic colloids (SLCs) was investigated. The SLCs structures were varied by different levels of protein (8 and $16 \%$, $\mathrm{w} / \mathrm{w})$, fat $(0,11,22$, and $33 \%, \mathrm{w} / \mathrm{w}), \mathrm{NaCl}(1.5 \%$ and $3.5 \%, \mathrm{w} / \mathrm{w})$, and homogenization pressure (14 and $55 \mathrm{MPa}$ ). Sodium release was measured while the SLCs were compressed in water. For SLCs with $1.5 \%$ and $3.5 \% \mathrm{NaCl}$, the porosity correlated positively with the maximum rate of sodium release. For the SLCs with $3.5 \% \mathrm{NaCl}$, the particle size of fat correlated negatively with the maximum concentration of released sodium and the area under the curve of sodium release profile. This study revealed that sodium release can be controlled via the convective transfer or diffusive transfer mechanisms by controlling the porosity and particle size of fat, respectively.

\section{Keywords}

solid lipoproteic colloid; sodium release; porosity; gyration radius of fat; serum release; texture 


\section{Introduction}

Engineering food structure to improve the sensory and nutritional qualities of the products has become one of the featuring areas in food science and food industry (Aguilera, 2005; Knoop et al., 2013; Norton et al., 2014; Stieger, 2011). Enhancing sodium release via engineering food structure has been proposed as one key strategy to allow a reduction in sodium content in processed foods (Stieger and van de Velde 2013; van de Velde and Adamse, 2013). Understanding the effect of food structure on the transport mechanisms of sodium can help tailoring the product formulation and process design for an efficient sodium delivery during mastication process.

Transport of sodium from porous food systems to the oral cavity can be achieved via convective and/or diffusive transfer (Geankoplis, 2003; Kuo and Lee, 2014a). In a convective transfer, sodium migrates with the fluid flowing from the food matrix into surroundings. Deformation of the food matrix due to oral processing can initiate outward fluid flow from the pores, resulting in serum release (van den Berg et al., 2007a). Sodium ions that are free of ionic interaction with the matrix are readily carried out by the serum. Previous studies showed the serum release of gels can be enhanced by increasing porosity, by forming a coarse-stranded network, or by forming a bicontinuous network of gels (van den Berg et al., 2007a, 2007b, 2008). Moreover, increasing serum release has been shown to enhance sodium release and saltiness perception (Stieger, 2011). However, the study by Stieger (2011) used model gels composed of proteins and polysaccharides. While many food products such as cheese and sausages contain emulsified fat, it has not been studied how the presence of fat can alter the serum release and sodium release. It has been demonstrated in meat products that a reduction of sodium by at least $15 \%$ was achieved by increasing the juiciness (van de Velde and Adamse, 2013). Still, the roles of fat particles in the above meat products were not examined.

While the driving force of convective transfer for sodium is the serum flow, the driving force for spontaneous diffusion of sodium is the concentration gradient of sodium across the food matrix and the surrounding oral cavity (Geankoplis, 2003; Kuo and Lee, 2014a). In model lipoproteic gel systems, decrease in particle size of fat caused increased extent of gel breakdown and thus increased surface area, allowing more sodium release (Boisard et al., 2013, 2014; de Loubens et al., 2011a, 2011b; Panouille et al., 2011). The 
above studies did not include the serum release of the gels. In another study on model lipoproteic gels, sodium release in mouth correlated positively with the water content of the gel (Lawrence et al., 2012; Phan et al., 2008).

Porosity and particle size of fat are critical factors affecting sodium release of lipoproteic foods, yet never studied together in a model food system. It is essential to study the effect of various structural properties together in the same food matrix to understand the role of structure in sodium release. The objective of this study is to correlate the structural properties, including porosity and particle size of fat, to the in vitro sodium release properties collected during the compression of solid lipoproteic colloids (SLC). The correlation of the structural properties to the temporal properties of sodium release further revealed the timedependent variation of sodium transport mechanisms throughout the gel compression process. The results will enhance the understanding of the saltiness perception of lipoproteic products such as cheese and sausages, as well as developing prototypes for sodium reduction.

\section{Material and Methods}

\subsection{Preparation of solid lipoproteic colloids (SLCs)}

The protocol for the preparation of the SLCs is detailed in previous literature (Kuo and Lee, 2014b; Kuo et al., 2016). Briefly, $\mathrm{NaCl}$ solutions containing whey protein isolate were homogenized with anhydrous milk fat using the APV 2-stage homogenizer (15 MR, SPX Flow Technology, Soeborg, Denmark), followed by heat-induced gelation by heating the emulsion at $90{ }^{\circ} \mathrm{C}$ for $30 \mathrm{~min}$ to form the SLCs. The SLCs varied by the contents of protein (8 and $16 \%, \mathrm{w} / \mathrm{w})$, fat $(0,11,22$, and $33 \%, \mathrm{w} / \mathrm{w}), \mathrm{NaCl}(1.5$ and $3.5 \%, \mathrm{w} / \mathrm{w})$, and homogenization pressures (14 and $55 \mathrm{MPa}$ ). The SLCs are coded according to their formula and homogenization pressure as protein $(\%, \mathrm{w} / \mathrm{w})$-fat $(\%, \mathrm{w} / \mathrm{w})$-pressure(MPa).

\subsection{Structural, textural and sodium release properties of the SLCs}

The protocols for acquiring the structural, textural and sodium release properties of the SLCs are detailed in previous literature (Kuo and Lee, 2014b; Kuo et al., 2016) unless additionally specified.

The images of the SLC internal structure were captured using an environmental scanning electron microscope (ESEM) with a field emission electron gun (FEI Co., Hillsboro, 
Oreg., U.S.A.) (Kuo and Lee, 2014b). The samples were freshly prepared and observed at the 1 Torr wet mode of the ESEM which allows characterizations of high-moisture samples without the need of prior drying (Donald 2003). The pores of the gel on the ESEM photos were identified using image analysis with the method described by Kuo and Lee (Kuo and Lee, 2014b). The porosity was calculated as the volume fraction of the pores relative to the total volume of the gel (Ryukhtin et al., 2003), assuming the pores are spherical. The gyration radius of fat particles $\left(\mathrm{r}_{\mathrm{g}, \mathrm{f}}\right)$ in the SLCs was determined using the Bonse-Hart double-crystal ultra-small-angle X-ray scattering (USAXS) instrument operated by ChemMatCARS at the Advanced Photon Source, Argonne National Laboratory (Argonne, IL, USA) (Kuo et al., 2016).

The textural properties, including serum release, maximum stress ( stress $_{\max }$ ), and strain at maximum stress ( $\left.\operatorname{strain}_{\max }\right)$ were measured by a compression test using a texture analyzer (TA-XT2i, Texture Technologies Corp., Scarsdale, N.Y., U.S.A.) (Kuo and Lee, 2014b).

The in vitro sodium release properties of the SLCs were determined by compressing the SLC in water using a texture analyzer (TA-XT2i, Texture Technologies Corp., Scarsdale, N.Y., U.S.A.), while recording the conductivity of the water using a conductivity probe (Orion DuraProbe 4-Electrode Conductivity Cells 013005MD) connected with an Orion VERSA STAR Multiparameter Benchtop Meter (Thermo Fisher Scientific Inc., Waltham, Mass, U.S.A.). The parameters extracted from the curve of sodium release included the maximum rate of sodium release $\left(\mathrm{R}_{\max }\right)$, the maximum concentration of released sodium $\left(\mathrm{C}_{\max }\right)$, and the area under the curve (AUC) of sodium release (Kuo and Lee, 2014b).

\subsection{Statistical analyses}

Analysis of variance (ANOVA) on each group of the SLCs with a constant level of $\mathrm{NaCl}$ was performed using SAS Software (SAS 9.3, SAS Inst., Inc., Cary, N.C., U.S.A.). The proc glm and the LSMEANS with the adjusted Tukey test were used to analyze the difference between the sample means.

Linear correlation, partial least square (PLS), and cluster analyses on each group of the SLCs with the same level of $\mathrm{NaCl}$ were performed using OriginPro 2015 (OriginLab Corporation, Northampton, MA, USA). These three analyses were performed on all the SLCs samples, and also on only the fat-containing SLCs. 
In the linear correlation, the treatment variables were correlated to the measured variables. The treatment variables in the linear correlation included the contents $(\mathrm{w} / \mathrm{w})$ of protein $(\mathrm{P} \%)$, fat $(\mathrm{F} \%)$ and water $(\mathrm{W} \%)$, the weight ratios of fat to protein $(\mathrm{F} / \mathrm{P})$, fat to water $(\mathrm{F} / \mathrm{W})$, protein to water $(\mathrm{P} / \mathrm{W})$, fat to solids $(\mathrm{F} / \mathrm{S})$, and homogenization pressure of the SLCs.

In the PLS analysis, the treatment and measured variables with significant and representative correlations were used as the $\mathrm{X}$ and $\mathrm{Y}$ variables, respectively. For each $\mathrm{Y}$ score PLS graph, cluster analysis with Euclidean distance and Ward's method was performed based on the Y-score variables.

\section{Results and Discussion}

\subsection{Effect of the treatments on the porosity of the SLCs}

Our previous studies have explored the microstructure of the SLCs using ESEM and USAXS (Kuo and Lee 2014b; Kuo et al., 2016). The SLCs are composed of a continuous protein network with varying average pore size $(0.4-2.3 \mu \mathrm{m}$, data not shown) and porosity depending on the formulation and treatment (Kuo and Lee 2014b). Protein aggregates with sizes below a hundred nanometers were the basic subunits of the SLC protein network (Kuo et al., 2016). For the fat-containing SLCs, spherical fat particles were homogeneously distributed within the protein network structure. The protein-fat interaction of the SLCs with $1.5 \% \mathrm{NaCl}$ was relatively stronger than in the SLCs with $3.5 \% \mathrm{NaCl}$, from which the fat particles were more easily observed under the ESEM (Kuo et al., 2016).

Varying treatments including compositions and homogenization pressure to prepare SLCs affected structural, textural, and sodium release properties (Table 1, 2, and 3). For the SLCs with $1.5 \% \mathrm{NaCl}$, the porosity correlated positively with the $\mathrm{W} \%$ and negatively with the F/S (Table 4). Similar trends were found in the SLCs with $3.5 \% \mathrm{NaCl}$, with higher levels of significance and greater values of the correlation coefficients than the SLCs with $1.5 \%$ $\mathrm{NaCl}$. This stronger dependence of porosity on the formula in the SLCs with $3.5 \% \mathrm{NaCl}$ compared to those with $1.5 \% \mathrm{NaCl}$ is further presented in the PLS graphs of the two sample groups (Fig. 1(a) and (b)). The positive correlation between the porosity and the W\% reflected the nature of porosity - originating from the voids filled with fluids in water-based gel network (van den Berg et al., 2007a, 2007b). Hence, increased water content of the gel generally leads to increased porosity (Kuo and Lee, 2014b). However, in the SLC systems, the porosity correlated stronger with the F/S ratio than with the water content. When 
comparing the selected samples with similar water contents, the effect of F/S ratio on porosity can be clearly seen. For example, the water contents of samples 8-33-14 and 16-2214 are similar; 57 and 59\% (w/w), respectively, and the F/S of the above two samples are 0.77 and 0.54 , respectively. The porosity of the former (53\%) is significantly lower than the porosity of the latter $(71 \%)$ (Table 1$)$. The difference in porosity can be attributed to the increased dispersion of the protein network when the increased volume of emulsion particles are present in the gel with increased F/S. Based on the ESEM images of the gel crosssections, sample 8-33-14 (Fig. 2(a)) contained finer and more homogeneous network with smaller pores compared to sample 16-22-14 (Fig. 2(b)). This relatively dispersed structure implied that the fat particles in sample 8-33-14 are well dispersed within the protein network. In contrast to sample 8-33-14, sample 16-22-14 contained coarse network formed by larger protein aggregates. The coarse structure implied more protein-protein interaction, which was due to lower F/S of sample 16-22-14 compared to sample 8-33-14. Hence, increase in fat content of lipoproteic gels can lead to enhanced dispersion of the network structure that takes up the gel internal space, and, thus yield decreased porosity of the gel. The similar effect of the F/S on the porosity can also be found between samples processed with $55 \mathrm{MPa}$; 8-33-55 and 16-22-55 (Table 1, Fig. 2(c) and (d)). The decrease in porosity with the reduction in pore sizes of the SLCs may be partially due to the detection limit of the ESEM. Based on the image resolution, the lowest pore diameter distinguishable in this study was $97.4 \mathrm{~nm}$. Pores with diameters below this limit could not be identified. Hence, compare to the sample 16-2214 , the low porosity of the sample 8-33-14 may be partially due to its greater portion of smaller pores that were beyond the detection limit.

\subsection{Effect of porosity on the textural properties of the SLCs}

Table 2 shows the textural properties of the SLCs. Linear correlation revealed the effect of the porosity on the textural and sodium release properties of the SLCs (Table 4). For both SLC groups with $1.5 \%$ and $3.5 \% \mathrm{NaCl}$, the porosity correlated positively with the serum release during the gel compression. This correlation has been previously discovered in polysaccharide/protein hybrid gels (Stieger and van de Velde, 2013; van den Berg et al., 2007a, 2007b) and SLCs with 1.5\% NaCl (Kuo and Lee, 2014b). As the pores in the waterbased gels are the void spaces occupied by fluid, increase in porosity implied increase in the amount of the stored liquid. When the gels are subjected to external force, deformation of the 
pore microstructure leads to rapid loss of the contained fluid, yielding serum release (van den Berg et al., 2007a).

However, for the SLCs with both levels of $\mathrm{NaCl}$, the correlation between porosity and serum release was contributed largely by the significantly greater porosity and serum release of the non-fat samples than those of the fat-containing samples. In fact, the porosity did not show a significant correlation with the serum release among only the fat-containing samples ( $\mathrm{P}=0.80$ and 0.07 for SLCs with 1.5 and $3.5 \% \mathrm{NaCl}$, respectively). This lack of correlation may be due to the effect of particle size of fat, $r_{g, f}$, which counteracted the effect of porosity in determining serum release. The presence of fat particles leads to earlier fracture, at less strain, of the fat-containing gels than the non-fat gels. Once the gel is fractured the applied stress is released and the potential for serum release by compression decreases (see section 3.5 for more discussion). Compared to the fat-containing SLCs, the non-fat SLCs showed relatively high values of $\operatorname{strain}_{\max }$ (Table 2). In fact, these non-fat SLCs only deformed without a fracture throughout the compression test. The serum was able to continuously migrate out from the non-fat SLCs during the compression and yielded in considerably higher serum release compared to the fat-containing SLCs.

The correlation between porosity and serum release was weaker in the SLCs with $1.5 \% \mathrm{NaCl}$, compared to the SLCs with 3.5\% NaCl (Table 4, Fig. 1(a) and (b)). The weaker correlation in the SLCs with $1.5 \% \mathrm{NaCl}$ was because the samples with the highest porosity (8-0-14 and 8-0-55) did not show the greatest serum release (Table 1 and 2). This discrepancy was due to the syneresis of the non-fat SLCs, which was not included in the serum release data. The observed syneresis from the non-fat SLCs was greater in the SLCs with $1.5 \%$ $\mathrm{NaCl}$, compared to those with $3.5 \% \mathrm{NaCl}$ (data not shown). The enhanced stability against syneresis of the SLCs with increased $\mathrm{NaCl}$ level may be due to increased charge screening. Screening effect is enhanced at elevated $\mathrm{NaCl}$ amount, which helps neutralize the surface charge and lessens the electrostatic repulsion between protein molecules. This improved screening can promote aggregation, branching, and densification of whey protein particles (Langton and Hermansson, 1996; Pouzot et al., 2004), strengthening the network structure (Hussain et al., 2012; Lorenzen and Schrader, 2006). Compared to the SLCs with $1.5 \% \mathrm{NaCl}$, the stronger and more stable structure of the SLCs with $3.5 \% \mathrm{NaCl}$ thus was able to retain more liquid before the measurement of serum release. 


\subsection{Effect of the porosity on the sodium release properties of the SLCs}

Among the three parameters extracted from the sodium release profiles, $\mathbf{R}_{\max }$ correlated positively with the porosity and the serum release at both levels of $\mathrm{NaCl}$ (Table 4). These correlations implied that the initial sodium release from the gel was mainly driven by the serum release during the gel compression. In the sodium release curve, $\mathrm{R}_{\max }$ reflects the fastest increment of sodium concentration in the beginning of the measurement. During this period the gel is undergoing the compression during which the serum is compressed out the most. Sodium thus is convectively transported by the serum flowing from the gel to the surrounding water. The rapid flow of serum from the gel resulted in the dramatic increase of sodium concentration in the surrounding water. As discussed in the correlation of porosity and serum release, the correlation of porosity and $\mathrm{R}_{\max }$ is weaker for the SLCs with $1.5 \%$ $\mathrm{NaCl}$ than with $3.5 \% \mathrm{NaCl}$ (Table 4, Fig. 1(a) and (b)). The above difference is partly attributed to the higher structural stability of the SLCs with $3.5 \% \mathrm{NaCl}$ than with $1.5 \% \mathrm{NaCl}$ to avoid water leaching before the sodium release measurement. In addition, compared to the SLCs with $1.5 \% \mathrm{NaCl}$, the stronger porosity $-\mathrm{R}_{\max }$ correlation for the SLCs with $3.5 \% \mathrm{NaCl}$ could be a result of their higher concentration of unassociated sodium ions with the protein, and, thus available for release upon a compression.

Although the serum release and sodium release were measured separately in this study, the force-distance curves recorded by the texture analyzer during the two types of measurements overlapped from each other. This consistency suggested that the texture of the samples did not differ between the regular compression test (for serum release) and the compression in water (for the sodium release). In addition to $\mathrm{R}_{\max }$, AUC also correlated positively to serum release. Since serum release did not correlate to $\mathrm{C}_{\max }$, it is hypothesized that the high $\mathrm{R}_{\max }$ contributed to the large AUC during initial sodium release, and in turn, to the overall AUC.

It has been shown that the perceived saltiness could be boosted by adding polysaccharide into sausages to increase the serum release (Stieger, 2011; van de Velde and Adamse, 2013). Alternatively, saltiness can be enhanced via high-pressure processing which yielded dry-cured hams with increased serum release (Clariana et al., 2012; Fulladosa et al., 2009, 2012). The sensory assessments in the above studies can be complemented by the instrumental evaluation of sodium release in the present study. Together, these studies supported that increasing porosity increases serum release, leading to increased sodium release during the initial gel deformation, and eventually boost saltiness perception. 
There were no correlations between the porosity, serum release, and the $\mathrm{R}_{\max }$ among only the fat-containing SLCs, for the SLCs with either NaCl levels (Table 5). The lack of correlation again indicated that the significant difference between the non-fat and fatcontaining SLC was the main contributor that resulted in the correlation between the porosity, serum release, and the $\mathrm{R}_{\max }$. This significant difference between the non-fat and the fat containing SLCs can be observed from the PLS plots of the SLCs (Fig. 1). For the SLCs with both $\mathrm{NaCl}$ levels (Fig. 1(c) and (d)), the non-fat SLCs are located at the far negative side along the axis of factor 1. Cluster analyses (data not shown) revealed that the non-fat SLCs were clustered in the region where the vectors of porosity, serum release, and $R_{\max }$ located (Fig. 1(a) and (c), Fig. 1(b) and (d)). The fat-containing samples were clustered in the region opposite from the non-fat samples. Linear correlation and PLS for only the fat-containing samples are necessary to observe the factors affecting sodium release of the fat-containing samples.

\subsection{Effect of the treatment on $r_{g, f}$ of SLCs}

The effect of treatment on $r_{g, f}$ of the SLCs has been investigated in previous literature (Kuo and Lee, 2014b; Kuo et al., 2016). Overall, the $r_{g, f}$ correlated negatively with the homogenization pressure (Table 5, Fig. 3(a) and (b)). The above correlation was highly significant for both groups of the SLCs with $1.5 \%$ and $3.5 \% \mathrm{NaCl}$. The result was expected as increased pressure during the homogenization provides increased shear which breaks down the fat particles more (Huppertz, 2011). At the same time, increased pressure induces an elevated degree of protein denaturation, improving the protein adsorption on the fat particles, and, thus improves emulsion stability (Lee et al., 2009). Regardless of the $\mathrm{NaCl}$ level in the SLCs, none of the variables in formulation correlated to $r_{\mathrm{g}, \mathrm{f}}$.

\subsection{Effect of the $r_{g, f}$ on the textural properties of the SLCs}

For the SLCs with both levels of $\mathrm{NaCl}$, the $\mathrm{r}_{\mathrm{g}, \mathrm{f}}$ correlated positively with the serum release (Table 5, Fig. 3(a) and (b)). This correlation is due to the shortened time to fracture of the gels with the reduced size of fat particles. Fat particles can be considered as structural defects that increase the stress concentration of the gel matrix (Sala et al., 2009; van Vliet et al., 1993), and, thus initiate fracture when the gel is subjected to external force. At the same level of fat content, the gels with a smaller particle size of fat indicated that the network is dispersed with a greater number of the structural defects. The gels with smaller fat particles 
are thus more likely to fracture earlier during the compression than the gels with larger fat particles (Sala and Stieger, 2013). According to the Darcy relation (Walstra, 2003), the volume flow rate of serum through the permeable area of a porous media is proportional to the pressure difference acting on the liquid over a given distance. The gel fracture would release the external pressure, which disfavors the serum release. The decrease in $r_{\mathrm{g}, \mathrm{f}}$ of the SLCs thus lead to shortened time to fracture and decreased serum release. The decrease in the time to fracture with the decrease in fat particle sizes can be evidenced by the positive correlation between the $r_{g, f}$ and the $\operatorname{strain}_{\max }$ of the SLCs with $3.5 \% \mathrm{NaCl}$.

\subsection{Effect of the $\mathbf{r}_{\mathrm{g}, \mathrm{f}}$ on the sodium release properties of the SLCs}

In the measurement of the sodium release, the rapid release of sodium via convective transfer by the serum may be mainly reflected by the $\mathrm{R}_{\max }$. Compare to the convective transfer, the slower sodium release via diffusion may be mainly reflected by the $\mathrm{C}_{\max }$ and AUC. The above difference is because that the $\mathrm{R}_{\max }$ represents the initial increment of sodium concentration following the gel compression. In contrast, the $\mathrm{C}_{\max }$ and $\mathrm{AUC}$ represent the final and cumulative concentration of sodium release into the surrounding water at the end of the measurement, respectively.

Among the sodium release parameters extracted, $\mathrm{C}_{\max }$ and AUC both correlated negatively with the $r_{g, f}$. However, these correlations only exist in the SLCs with $3.5 \% \mathrm{NaCl}$ (Table 5, Fig. 3(a) and (b)). These correlations can be linked to the correlation between the $\mathrm{r}_{\mathrm{g}, \mathrm{f}}$ and the $\operatorname{strain}_{\max }$ for the SLCs with $3.5 \% \mathrm{NaCl}$. As mentioned in section 3.5, the SLCs with smaller $r_{g, f}$ fracture earlier during the compression than SLCs with larger $r_{g, f}$. Shortened time to fracture could lead to increased number fragmented debris of the gel, and, hence increased the total surface area of emulsion-filled gels (Sala and Stieger, 2013). In the measurement of sodium release, the earlier and more extensive the gel breaks down, the more sodium can diffuse out from the newly formed surface area of the debris (Koliandris et al., 2008; de Loubens et al., 2011a; Panouille et al., 2011). The increased total area after the fracture of the SLCs would, therefore, favor the diffusive sodium release, and yield elevated $\mathrm{C}_{\max }$ and AUC. It is worth noticing that for the SLCs with $3.5 \% \mathrm{NaCl}, \mathrm{R}_{\max }$ correlated positively with the homogenization pressure (Table 5, Fig. 3 (b)). This positive correlation may not be associated with the serum release, as serum release was not correlated to either the homogenization pressure or $\mathrm{R}_{\max }$. Instead, the correlation between the $\mathrm{R}_{\max }$ and 
homogenization pressure may be partly attributed to the reduced ionic interaction between sodium and protein with increased pressure (Clariana et al., 2011; Picouet et al., 2012).

Compared to the SLCs with $3.5 \% \mathrm{NaCl}$, the lack of the correlation between the $\mathrm{r}_{\mathrm{g}, \mathrm{f}}$, strain $_{\max }, \mathrm{C}_{\max }$ and AUC in the SLCs with $1.5 \% \mathrm{NaCl}$ may be attributed to the lower interprotein interaction at lower $\mathrm{NaCl}$ content. As discussed in the previous literature (Langton and Hermansson, 1996; Pouzot et al., 2004), an increase in $\mathrm{NaCl}$ level strengthens the gel networks, due to the screening effect of $\mathrm{NaCl}$. Compared to the SLCs with $1.5 \% \mathrm{NaCl}$, the stronger inter-protein interaction in the SLCs with 3.5\% $\mathrm{NaCl}$ could, therefore, yield a network where the initiation of fracture more likely occurs at the protein-fat interface (Kuo et al., 2016). Hence the effect of the $r_{g, f}$ on the gel fracture, and thus, the sodium release, is more evident in the $\mathrm{SLCs}$ with $3.5 \% \mathrm{NaCl}$ than with $1.5 \% \mathrm{NaCl}$. The difference in the effect of $r_{\mathrm{g}, \mathrm{f}}$ between the $1.5 \%$ and $3.5 \%$ SLCs can be visualized by their PLS graphs (Fig. 3(c) and (d)). The cluster analysis of the SLCs with $1.5 \% \mathrm{NaCl}$ indicated that the samples were grouped primarily based on the serum release (Fig. 3(a) and (c)). The cluster located on the positive side of the serum release vector contained the SLCs with lower fat contents, as compared to the other cluster. By comparison, the SLCs with $3.5 \% \mathrm{NaCl}$ were grouped primarily based on the $r_{g, f}$ and the sodium release properties (Fig. 3(b) and (d)). The cluster located along the positive direction of the $r_{g, f}$ vector contained the SLCs made with lower homogenization pressure, and featured with lower values of $\mathrm{R}_{\max }, \mathrm{C}_{\max }$, and AUC, as compared to the other cluster.

The present study revealed the two potential structural adjustments to enhance sodium release. The maximum rate of sodium release can be boosted via increasing the porosity and thus serum release. The maximum concentration and the cumulative concentration of the released sodium can be boosted via reducing the particle size of fat and hence facilitating the gel fracture. Nevertheless, the counteracting effect of $r_{g, f}$ on the serum release and the gel fragmentation requires further investigation. Indeed, sensory methods will be required to answer whether enhanced serum release led by increased porosity and fat particle size, or increased fragmentation led by reduced fat particles size in the gel, is more critical to enhancing the perceived saltiness. Compared to the gel fragmentation, our most recent study has shown a more significant impact of serum release on saltiness perception of the SLCs (data not included). 


\section{Conclusions}

In this study, the effect of treatment on the structural properties of the solid lipoproteic colloids (SLCs) was evaluated. Also, the effect of structural properties on the textural and sodium release properties of the SLCs was investigated. For both SLCs with $1.5 \%$ and $3.5 \% \mathrm{NaCl}$, water content $(\mathrm{W} \%)$ and the weight ratio of fat to solid $(\mathrm{F} / \mathrm{S})$ correlated positively and negatively with the porosity, respectively. The porosity correlated positively with serum release and the maximum rate of sodium release $\left(\mathrm{R}_{\max }\right)$. These correlations indicated that convective transport via serum flow is the main driving force of sodium release during the gel compression. For both SLCs with $1.5 \%$ and $3.5 \% \mathrm{NaCl}$, the gyration radius of fat particles $\left(\mathrm{r}_{\mathrm{g}, \mathrm{f}}\right)$ correlated negatively with the homogenization pressure. For the SLCs with $3.5 \% \mathrm{NaCl}$, the $\mathrm{r}_{\mathrm{g}, \mathrm{f}}$ correlated positively with the strain at maximum stress ( $\operatorname{strain}_{\max }$ ) and negatively with the maximum concentration of released sodium $\left(\mathrm{C}_{\max }\right)$ as well as the area under the curve of sodium release (AUC). These correlations indicated that, after the gel fracture, the diffusive transport of sodium release via the new surfaces is the main driving force of sodium release. The lack of such correlations in the SLCs with $1.5 \% \mathrm{NaCl}$ suggested the stronger inter-protein interaction in the SLCs with $3.5 \% \mathrm{NaCl}$ than with $1.5 \% \mathrm{NaCl}$. The results of this study suggested the rules of porosity and particle size of fat in governing the convective and diffusive transport for sodium release during different stages of gel breakdown. The findings will help understand the temporal saltiness perception of the SLCs. Combining this study with future sensory evaluations on the SLCs will provide potential strategies for sodium reduction in lipoproteic products via effective sodium release.

\section{Acknowledgement}

This work was supported by the U.S. Department of Agriculture via the National Institute of Food and Agriculture Grant [grant number 2015-67017-23089]. This research used resources of the Advanced Photon Source, a U.S. Department of Energy (DOE) Office of Science User Facility operated for the DOE Office of Science by Argonne National Laboratory under Contract No. DE-AC02-06CH11357. 


\section{References}

Aguilera, J.M., 2005. Why food microstructure? IV Iberoam. Congr. Food Eng. (CIBIA IV) 67,3-11. doi:http://dx.doi.org/10.1016/j.jfoodeng.2004.05.050

Boisard, L., Andriot, I., Arnould, C., Achilleos, C., Salles, C., Guichard, E., 2013. Structure and composition of model cheeses influence sodium NMR mobility, kinetics of sodium release and sodium partition coefficients. Food Chem. 136, 1070-1077. doi:http://dx.doi.org/10.1016/j.foodchem.2012.09.035

Boisard, L., Andriot, I., Martin, C., Septier, C., Boissard, V., Salles, C., Guichard, E., 2014. The salt and lipid composition of model cheeses modifies in-mouth flavour release and perception related to the free sodium ion content. Food Chem. 145, 437-444. doi:http://dx.doi.org/10.1016/j.foodchem.2013.08.049

Clariana, M., Guerrero, L., Sárraga, C., Díaz, I., Valero, Á., García-Regueiro, J.A., 2011. Influence of high pressure application on the nutritional, sensory and microbiological characteristics of sliced skin vacuum packed dry-cured ham. Effects along the storage period. Innov. Food Sci. Emerg. Technol. 12, 456-465. doi:10.1016/j.ifset.2010.12.008

Clariana, M., Guerrero, L., Sarraga, C., Garcia-Regueiro, J.A., 2012. Effects of high pressure application (400 and $900 \mathrm{MPa}$ ) and refrigerated storage time on the oxidative stability of sliced skin vacuum packed dry-cured ham. Meat Sci. 90, 323-329. doi:10.1016/j.meatsci.2011.07.018

de Loubens, C., Panouillé, M., Saint-Eve, A., Déléris, I., Tréléa, I.C., Souchon, I., 2011a. Mechanistic model of in vitro salt release from model dairy gels based on standardized breakdown test simulating mastication. J. Food Eng. 105, 161-168. doi:10.1016/j.jfoodeng.2011.02.020

de Loubens, C., Saint-Eve, A., Deleris, I., Panouille, M., Doyennette, M., Trelea, I.C., Souchon, I., 2011b. Mechanistic model to understand in vivo salt release and perception during the consumption of dairy gels. J. Agric. Food Chem. 59, 2534-2542. doi:10.1021/jf103792b

Donald, A.M., 2003. The use of environmental scanning electron microscopy for imaging wet and insulating materials. Nat. Mater. 2, 511-516.

Fulladosa, E., Sala, X., Gou, P., Garriga, M., Arnau, J., 2012. K-lactate and high pressure effects on the safety and quality of restructured hams. Meat Sci. 91, 56-61. 
Fulladosa, E., Serra, X., Gou, P., Arnau, J., 2009. Effects of potassium lactate and high pressure on transglutaminase restructured dry-cured hams with reduced salt content. Meat Sci. 82, 213-218. doi:10.1016/j.meatsci.2009.01.013

Geankoplis, C.J., 2003. Principles of unsteady-state and convective mass transfer, in: Geankoplis, C.J. (Ed.), Transport Processes and Separation Process Principles. Prentice Hall, Upper Saddle River, New Jersey, pp. 459-512.

Huppertz, T., 2011. Homogenization of milk | High-pressure homogenizers, in: Fuquay, J.W. (Ed.), Encyclopedia of Dairy Sciences (Second Edition). Academic Press, San Diego, pp. 755-760. doi:http://dx.doi.org.proxy2.library.illinois.edu/10.1016/B978-0-12374407-4.00225-9

Hussain, R., Gaiani, C., Jeandel, C., Ghanbaja, J., Scher, J., 2012. Combined effect of heat treatment and ionic strength on the functionality of whey proteins. J. Dairy Sci. 95, 6260-6273. doi:http://dx.doi.org/10.3168/jds.2012-5416

Knoop, J.E., Sala, G., Smit, G., Stieger, M., 2013. Combinatory effects of texture and aroma modification on taste perception of model gels. Chemosens. Percept. 6, 60-69. doi:10.1007/s12078-013-9141-4

Koliandris, A., Lee, A., Ferry, A.-L., Hill, S., Mitchell, J., 2008. Relationship between structure of hydrocolloid gels and solutions and flavour release. Food Hydrocoll. 22, 623-630. doi:10.1016/j.foodhyd.2007.02.009

Kuo, W.-Y., Ilavsky, J., Lee, Y., 2016. Structural characterization of solid lipoproteic colloid gels by ultra-small-angle X-ray scattering and the relation with sodium release. Food Hydrocoll. 56, 325-333. doi:http://dx.doi.org/10.1016/j.foodhyd.2015.12.032

Kuo, W.-Y., Lee, Y., 2014a. Effect of food matrix on saltiness perception-Implications for sodium reduction. Compr. Rev. Food Sci. Food Saf. 13, 906-923. doi:10.1111/15414337.12094

Kuo, W.-Y., Lee, Y., 2014b. Temporal sodium release related to gel microstructural properties-Implications for sodium reduction. J. Food Sci. 79, E2245-E2252. doi:10.1111/1750-3841.12669

Langton, M., Hermansson, A.-M., 1996. Image analysis of particulate whey protein gels. Food Hydrocoll. 10, 179-191. doi:http://dx.doi.org/10.1016/S0268-005X(96)80033-6 
Lawrence, G., Buchin, S., Achilleos, C., Berodier, F., Septier, C., Courcoux, P., Salles, C., 2012. In Vivo Sodium Release and Saltiness Perception in Solid Lipoprotein Matrices. 1. Effect of Composition and Texture. J. Agric. Food Chem. 60, 5287-5298. doi:10.1021/jf204434t

Lee, S.-H., Lefèvre, T., Subirade, M., Paquin, P., 2009. Effects of ultra-high pressure homogenization on the properties and structure of interfacial protein layer in whey protein-stabilized emulsion. Food Chem. 113, 191-195. doi:http://dx.doi.org/10.1016/j.foodchem.2008.07.067

Lorenzen, P.C., Schrader, K., 2006. A comparative study of the gelation properties of whey protein concentrate and whey protein isolate. Lait 86, 259-271. doi:10.1051/lait:2006008

Norton, J.E., Wallis, G.A., Spyropoulos, F., Lillford, P.J., Norton, I.T., 2014. Designing food structures for nutrition and health benefits. Annu. Rev. Food Sci. Technol. 5, 177-195. doi:10.1146/annurev-food-030713-092315

Panouille, M., Saint-Eve, A., de Loubens, C.C., Deleris, I., Souchon, I., Panouillé, M., SaintEve, A., de Loubens, C.C., Déléris, I., Souchon, I., Panouille, M., Saint-Eve, A., de Loubens, C.C., Deleris, I., Souchon, I., Panouillé, M., Saint-Eve, A., de Loubens, C.C., Déléris, I., Souchon, I., Panouille, M., Saint-Eve, A., de Loubens, C.C., Deleris, I., Souchon, I., 2011. Understanding of the influence of composition, structure and texture on salty perception in model dairy products. Food Hydrocoll. 25, 716-723. doi:10.1016/j.foodhyd.2010.08.021

Phan, V.A., Yven, C., Lawrence, G., Chabanet, C., Reparet, J.M., Salles, C., 2008. In vivo sodium release related to salty perception during eating model cheeses of different textures. Int. Dairy J. 18, 956-963. doi:10.1016/j.idairyj.2008.03.015

Picouet, P.A., Sala, X., Garcia-Gil, N., Nolis, P., Colleo, M., Parella, T., Arnau, J., 2012. High pressure processing of dry-cured ham: Ultrastructural and molecular changes affecting sodium and water dynamics. Innov. Food Sci. Emerg. Technol. 16, 335-340. doi:10.1016/j.ifset.2012.07.008

Pouzot, M., Durand, D., Nicolai, T., 2004. Influence of the ionic strength on the structure of heat-set globular protein gels at $\mathrm{pH}$ 7. beta-lactoglobulin. Macromolecules 37, 8703- 
469

470

471

472

473

474

475

476

477

478

479

480

481

482

483

484

485

486

487

488

489

490

491

492

493

494

495

496

497

498

Ryukhtin, V., Šaroun, J., Harjo, S., Motohashi, Y., Baron, M., Loidl, R., 2003. Comparative study of porosity in 3Y-TZP superplastic ceramics by ultra-small-angle neutron scattering and scanning electron microscopy image analysis. J. Appl. Crystallogr. 36, $478-483$.

Sala, G., Stieger, M., 2013. Time to first fracture affects sweetness of gels. Food Hydrocoll. 30, 73-81. doi:10.1016/j.foodhyd.2012.05.003

Sala, G., van Vliet, T., Cohen Stuart, M.A., Aken, G.A. van, van de Velde, F., 2009. Deformation and fracture of emulsion-filled gels: Effect of oil content and deformation speed. Food Hydrocoll. 23, 1381-1393.

doi:http://dx.doi.org.proxy2.library.illinois.edu/10.1016/j.foodhyd.2008.11.016

Stieger, M., 2011. Texture-taste interactions: Enhancement of taste intensity by structural modifications of the food matrix. 11th Int. Congr. Eng. Food 1, 521-527. doi:10.1016/j.profoo.2011.09.079

Stieger, M., van de Velde, F., 2013. Microstructure, texture and oral processing: New ways to reduce sugar and salt in foods. Curr. Opin. Colloid Interface Sci. 18, 334-348. doi:http://dx.doi.org/10.1016/j.cocis.2013.04.007

van de Velde, F., Adamse, M., 2013. Juiciness enhances the perceived saltiness of meat products. New Food Magazine 2. Retrieved from http://www.newfoodmagazine.com/10597/new-food-magazine/past-issues/issue-22013/juiciness-enhances-the-perceived-saltiness-of-meat-products/

van den Berg, L., van Vliet, T., van der Linden, E., van Boekel, M.A.J.S., van de Velde, F., 2007a. Serum release: The hidden quality in fracturing composites. Food Hydrocoll. 21, 420-432. doi:http://dx.doi.org/10.1016/j.foodhyd.2006.05.002

van den Berg, L., van Vliet, T., van der Linden, E., van Boekel, M.A.J.S., van de Velde, F., 2007b. Breakdown properties and sensory perception of whey proteins/polysaccharide mixed gels as a function of microstructure. Food Colloids 2006 21, 961-976. doi:http://dx.doi.org.proxy2.library.illinois.edu/10.1016/j.foodhyd.2006.08.017

van den Berg, L., van Vliet, T., van der Linden, E., van Boekel, M.A.J.S., van de Velde, F., 2008. Physical properties giving the sensory perception of whey proteins/polysaccharide gels. Food Biophys. 3, 198-206. doi:10.1007/s11483-008-9084-5 
van Vliet, T., Luyten, H., Walstra, P., 1993. Time-dependent fracture-behavior of food. R.

500 Soc. Chem. Spec. Publ. 113, 175-190.

501 Walstra, P., 2003. Physical chemistry of foods. Marcel Dekker, Wageningen Univ.

502 Wageningen, Netherlands.

508 
Table 1.

508 Porosity and the gyration radius of fat $\left(\mathrm{r}_{\mathrm{g}, \mathrm{f}}\right)$ of the SLCs ${ }^{1}$.

\begin{tabular}{|c|c|c|c|}
\hline $\begin{array}{c}\mathrm{NaCl} \\
(\%, \mathrm{w} / \mathrm{w})\end{array}$ & Sample $^{2}$ & $\begin{array}{c}\text { Porosity } \pm \text { SD } \\
(\%)\end{array}$ & $\begin{array}{c}\mathrm{r}_{\mathrm{g}, \mathrm{f}} \\
(\mathrm{nm})\end{array}$ \\
\hline \multirow{16}{*}{1.5} & $8-0-14$ & $71.84 \pm 5.16 \mathrm{ab}$ & - \\
\hline & $8-0-55$ & $75.77 \pm 2.02 \mathrm{a}$ & - \\
\hline & $8-11-14$ & $54.80 \pm 4.38 \mathrm{cdef}$ & 449.3 \\
\hline & $8-11-55$ & $65.47 \pm 2.57 \mathrm{abcd}$ & 120.5 \\
\hline & $8-22-14$ & $62.34 \pm 7.14$ abcde & 484.6 \\
\hline & $8-22-55$ & $56.02 \pm 0.64$ bcdef & 125.8 \\
\hline & $8-33-14$ & $53.38 \pm 1.20 \mathrm{def}$ & 319.3 \\
\hline & $8-33-55$ & $48.48 \pm 1.76 f$ & 121.2 \\
\hline & $16-0-14$ & $61.05 \pm 1.34$ abcde & - \\
\hline & $16-0-55$ & $71.71 \pm 6.08 \mathrm{ab}$ & - \\
\hline & $16-11-14$ & $55.61 \pm 2.26$ bcdef & 457.5 \\
\hline & $16-11-55$ & $43.30 \pm 6.36 \mathrm{f}$ & 153.6 \\
\hline & $16-22-14$ & $70.85 \pm 0.78 a b c$ & 325.2 \\
\hline & $16-22-55$ & $58.75 \pm 6.29$ bcde & 113.6 \\
\hline & $16-33-14$ & $58.82 \pm 0.14$ bcde & 274 \\
\hline & $16-33-55$ & $57.35 \pm 8.27$ bcdef & 101 \\
\hline \multirow{16}{*}{3.5} & $8-0-14$ & $72.72 \pm 5.88 \mathrm{a}$ & - \\
\hline & $8-0-55$ & $73.31 \pm 1.70 \mathrm{a}$ & - \\
\hline & 8-11-14 & $62.46 \pm 2.42 a b c$ & 371.5 \\
\hline & $8-11-55$ & $62.93 \pm 5.43 a b c$ & 125.2 \\
\hline & $8-22-14$ & $58.15 \pm 5.62 \mathrm{abc}$ & 387.3 \\
\hline & $8-22-55$ & $41.93 \pm 8.63 \mathrm{abc}$ & 121.6 \\
\hline & $8-33-14$ & $50.61 \pm 3.25 b c$ & 291.2 \\
\hline & $8-33-55$ & $49.65 \pm 7.42 \mathrm{c}$ & 110.1 \\
\hline & $16-0-14$ & $72.06 \pm 8.14 \mathrm{a}$ & - \\
\hline & $16-0-55$ & $68.33 \pm 4.68 \mathrm{ab}$ & - \\
\hline & $16-11-14$ & $61.84 \pm 2.19 a b c$ & 711 \\
\hline & $16-11-55$ & $48.46 \pm 0.92 \mathrm{c}$ & 91.2 \\
\hline & $16-22-14$ & $54.82 \pm 1.13 \mathrm{abc}$ & 407.8 \\
\hline & $16-22-55$ & $59.37 \pm 8.56 \mathrm{abc}$ & 77.4 \\
\hline & $16-33-14$ & $53.40 \pm 0.71 \mathrm{abc}$ & N.D. ${ }^{3}$ \\
\hline & $16-33-55$ & $54.07 \pm 8.58 \mathrm{abc}$ & 66.3 \\
\hline
\end{tabular}

1. The numbers followed by the same letters within the group of same $\mathrm{NaCl}$ content are not significantly different.

2. The SLCs are coded according to their formula and homogenization pressure as protein $(\%, w / w)-f a t(\%, w / w)-p r e s s u r e(M P a)$.

3. The value was not measured due to an operation error. 
Table 2.

516 Properties of the SLCs measured by a compression test using a texture analyzer ${ }^{1}$.

\begin{tabular}{|c|c|c|c|c|c|}
\hline $\begin{array}{c}\mathrm{NaCl} \\
(\%, \mathrm{w} / \mathrm{w})\end{array}$ & Sample $^{2}$ & $\begin{array}{c}\text { Serum }^{3} \\
\pm \text { SD }(g)\end{array}$ & $\begin{array}{r}\text { Stress }_{\max } \\
\pm \mathrm{SD}(\mathrm{KP}\end{array}$ & & $\begin{array}{l}\text { Strain }_{\max } \\
\pm \text { SD }(\%)\end{array}$ \\
\hline \multirow{16}{*}{1.5} & $8-0-14$ & $2.85 \pm 0.42 b$ & $69.91 \pm 3.25$ & $\mathrm{e}$ & $79.90 \pm 0.14 \mathrm{ab}$ \\
\hline & $8-0-55$ & $2.47 \pm 0.21 \mathrm{c}$ & $53.41 \pm 8.27$ & $\mathrm{e}$ & $79.82 \pm 0.35 \mathrm{ab}$ \\
\hline & $8-11-14$ & $0.96 \pm 0.07 \mathrm{~d}$ & $65.26 \pm 10.96$ & $\mathrm{e}$ & $73.81 \pm 1.98$ abc \\
\hline & $8-11-55$ & $0.63 \pm 0.06 \mathrm{fg}$ & $51.58 \pm 8.60$ & $\mathrm{e}$ & $59.54 \pm 1.28 \mathrm{abc}$ \\
\hline & $8-22-14$ & $0.74 \pm 0.07 \mathrm{ef}$ & $58.90 \pm 0.28$ & $\mathrm{e}$ & $62.86 \pm 0.99 a b c$ \\
\hline & $8-22-55$ & $0.52 \pm 0.04 \mathrm{fgh}$ & $93.07 \pm 9.37$ & $\mathrm{e}$ & $55.08 \pm 1.86 \mathrm{bc}$ \\
\hline & $8-33-14$ & $0.48 \pm 0.04$ fghi & $100.92 \pm 17.98$ & de & $59.78 \pm 3.42 \mathrm{abc}$ \\
\hline & $8-33-55$ & $0.30 \pm 0.00 \mathrm{hi}$ & $169.72 \pm 21.49$ & $\mathrm{~cd}$ & $55.87 \pm 3.17 b c$ \\
\hline & $16-0-14$ & $4.39 \pm 0.14 \mathrm{a}$ & $293.18 \pm 100.13$ & $\mathrm{ab}$ & $79.99 \pm 0.00 \mathrm{ab}$ \\
\hline & $16-0-55$ & $4.66 \pm 0.06 \mathrm{a}$ & $256.62 \pm 37.48$ & $\mathrm{ab}$ & $79.99 \pm 0.00 a$ \\
\hline & $16-11-14$ & $0.77 \pm 0.11 \mathrm{e}$ & $236.21 \pm 20.60$ & $a b c$ & $78.06 \pm 3.58 \mathrm{ab}$ \\
\hline & $16-11-55$ & $0.45 \pm 0.06$ ghi & $216.36 \pm 50.66$ & $a b c$ & $67.92 \pm 2.04 \mathrm{abc}$ \\
\hline & $16-22-14$ & $0.47 \pm 0.00 \mathrm{fghi}$ & $309.21 \pm 61.90$ & $\mathrm{a}$ & $76.92 \pm 2.54 \mathrm{ab}$ \\
\hline & $16-22-55$ & $0.25 \pm 0.07 \mathrm{hi}$ & $270.17 \pm 31.73$ & $a b$ & $59.76 \pm 4.00 \quad \mathrm{abc}$ \\
\hline & $16-33-14$ & $0.12 \pm 0.00 \mathrm{i}$ & $192.87 \pm 34.65$ & bcd & $48.01 \pm 8.77 \mathrm{c}$ \\
\hline & $16-33-55$ & $0.20 \pm 0.00 \mathrm{hi}$ & $201.60 \pm 41.44$ & $a b c$ & $73.89 \pm 47.66 \mathrm{abc}$ \\
\hline \multirow{16}{*}{3.5} & $8-0-14$ & $3.26 \pm 0.31 \mathrm{a}$ & $55.40 \pm 14.53$ & $\mathrm{~d}$ & $80.00 \pm 0.00 \quad \mathrm{a}$ \\
\hline & $8-0-55$ & $3.39 \pm 0.00 \mathrm{a}$ & $62.07 \pm 2.63$ & $\mathrm{~d}$ & $79.85 \pm 0.29 \quad \mathrm{a}$ \\
\hline & $8-11-14$ & $1.08 \pm 0.13 b$ & $76.47 \pm 19.57$ & $\mathrm{~cd}$ & $76.62 \pm 2.37 \mathrm{ab}$ \\
\hline & $8-11-55$ & $0.86 \pm 0.06 b$ & $59.83 \pm 9.05$ & d & $60.55 \pm 1.62$ cdef \\
\hline & $8-22-14$ & $0.83 \pm 0.06 b$ & $71.11 \pm 14.09$ & $\mathrm{~cd}$ & $66.14 \pm 2.67$ bcde \\
\hline & $8-22-55$ & $0.49 \pm 0.10 b$ & $112.25 \pm 15.81$ & bcd & $54.08 \pm 3.42$ efg \\
\hline & $8-33-14$ & $0.47 \pm 0.00 b$ & $101.22 \pm 3.90$ & bcd & $60.28 \pm 1.99$ cdef \\
\hline & $8-33-55$ & $0.30 \pm 0.10 b$ & $166.29 \pm 29.47$ & bcd & $56.41 \pm 1.12 \mathrm{defg}$ \\
\hline & $16-0-14$ & $3.83 \pm 1.56 \mathrm{a}$ & $213.83 \pm 37.96$ & $a b$ & $78.68 \pm 2.31 \quad \mathrm{a}$ \\
\hline & $16-0-55$ & $3.22 \pm 1.12 \mathrm{a}$ & $331.76 \pm 156.48$ & $\mathrm{a}$ & $78.25 \pm 2.47 \mathrm{ab}$ \\
\hline & $16-11-14$ & $0.90 \pm 0.00 b$ & $142.21 \pm 47.96$ & bcd & $64.65 \pm 0.78$ bcde \\
\hline & $16-11-55$ & $0.47 \pm 0.06 b$ & $179.14 \pm 16.01$ & bcd & $46.30 \pm 2.03 \mathrm{~g}$ \\
\hline & $16-22-14$ & $0.42 \pm 0.07 b$ & $206.26 \pm 42.92$ & $a b c$ & $73.60 \pm 2.55 \mathrm{abc}$ \\
\hline & $16-22-55$ & $0.22 \pm 0.00 b$ & $214.87 \pm 53.25$ & $a b$ & $45.06 \pm 15.63 \mathrm{~g}$ \\
\hline & $16-33-14$ & $0.17 \pm 0.00 b$ & $152.86 \pm 88.03$ & bcd & $67.99 \pm 9.62 \mathrm{abcd}$ \\
\hline & $16-33-55$ & $0.07 \pm 0.06 \mathrm{~b}$ & $322.11 \pm 20.73$ & $\mathrm{a}$ & $51.72 \pm 3.80 \mathrm{fg}$ \\
\hline
\end{tabular}

1. The numbers followed by the same letters within the group of same $\mathrm{NaCl}$ content are not significantly different.

2. The SLCs are coded according to their formula and homogenization pressure as $\operatorname{protein}(\%, w / w)-f a t(\%, w / w)-p r e s s u r e(M P a)$.

3. Serum, amount of liquid expelled from the sample during the compression test; Stress ${ }_{\max }$, maximum stress measured during the compression test; $\operatorname{Strain}_{\max }$, strain at the maximum stress. 
Table 3.

526 Properties obtained from the sodium release profile of the SLCs ${ }^{1}$.

\begin{tabular}{|c|c|c|c|c|c|}
\hline $\begin{array}{c}\mathrm{NaCl} \\
(\%, \mathrm{w} / \mathrm{w})\end{array}$ & Sample $^{2}$ & $\begin{array}{l}\mathrm{R}_{\max } \pm \mathrm{SD}^{3} \\
(\mathrm{ppm} \mathrm{Na} / \mathrm{s})\end{array}$ & $\begin{array}{l}\mathrm{C}_{\max } \pm \mathrm{SD} \\
(\mathrm{ppm} \mathrm{Na})\end{array}$ & $\begin{array}{c}\text { AUC } \pm \text { SD } \\
\left(10^{3} \mathrm{ppm} \mathrm{Na.s}\right)\end{array}$ & \\
\hline \multirow{16}{*}{1.5} & $8-0-14$ & $4.57 \pm 0.35 \mathrm{ab}$ & $60.44 \pm 1.98 \mathrm{ab}$ & $20.26 \pm 0.49$ & $\overline{b c}$ \\
\hline & $8-0-55$ & $2.99 \pm 0.74 b c$ & $50.32 \pm 2.95 \mathrm{ab}$ & $15.73 \pm 1.12$ & defg \\
\hline & $8-11-14$ & $0.73 \pm 0.21 \mathrm{de}$ & $45.25 \pm 8.98 \quad a b$ & $12.49 \pm 2.55$ & ghi \\
\hline & $8-11-55$ & $0.71 \pm 0.14 \mathrm{de}$ & $69.35 \pm 4.74 \mathrm{ab}$ & $15.89 \pm 1.27$ & cdefg \\
\hline & $8-22-14$ & $0.77 \pm 0.14 \mathrm{de}$ & $64.14 \pm 6.43 a b$ & $16.06 \pm 0.49$ & cdefg \\
\hline & $8-22-55$ & $0.74 \pm 0.17 \mathrm{de}$ & $75.90 \pm 3.83 \mathrm{ab}$ & $16.58 \pm 1.38$ & cdef \\
\hline & 8-33-14 & $0.73 \pm 0.10 \mathrm{de}$ & $76.20 \pm 6.49 \mathrm{ab}$ & $16.80 \pm 1.51$ & cde \\
\hline & $8-33-55$ & $0.82 \pm 0.19 \mathrm{de}$ & $79.13 \pm 3.86 \mathrm{ab}$ & $17.72 \pm 0.97$ & $\mathrm{~cd}$ \\
\hline & $16-0-14$ & $5.26 \pm 2.05 \mathrm{a}$ & $79.70 \pm 10.89 a b$ & $29.54 \pm 0.92$ & $\mathrm{a}$ \\
\hline & $16-0-55$ & $6.25 \pm 0.21 \mathrm{a}$ & $90.99 \pm 2.12 \quad \mathrm{a}$ & $31.28 \pm 0.14$ & $\mathrm{a}$ \\
\hline & $16-11-14$ & $0.34 \pm 0.11 \mathrm{e}$ & $33.83 \pm 4.39 b$ & $8.02 \pm 0.95$ & $\mathrm{ij}$ \\
\hline & $16-11-55$ & $0.36 \pm 0.12 \mathrm{e}$ & $43.23 \pm 7.01 \mathrm{ab}$ & $9.68 \pm 1.79$ & hi \\
\hline & $16-22-14$ & $0.34 \pm 0.07 \mathrm{de}$ & $79.93 \pm 65.97 \mathrm{ab}$ & $8.10 \pm 0.85$ & $\mathrm{ij}$ \\
\hline & $16-22-55$ & $0.60 \pm 0.14 \mathrm{de}$ & $59.09 \pm 0.57 \mathrm{ab}$ & $13.20 \pm 0.14$ & efgh \\
\hline & $16-33-14$ & $0.58 \pm 0.07 \mathrm{de}$ & $73.59 \pm 23.41 \mathrm{ab}$ & $12.64 \pm 0.64$ & fghi \\
\hline & $16-33-55$ & $1.89 \pm 0.42 \mathrm{~cd}$ & $73.21 \pm 40.73 \mathrm{ab}$ & $23.21 \pm 1.70$ & $\mathrm{~b}$ \\
\hline \multirow{16}{*}{3.5} & $8-0-14$ & $10.76 \pm 0.87 \mathrm{a}$ & $149.01 \pm 22.62 \mathrm{abcd}$ & $50.07 \pm 7.70$ & $\mathrm{ab}$ \\
\hline & $8-0-55$ & $10.01 \pm 2.17 \mathrm{a}$ & $140.60 \pm 8.75 \mathrm{abcd}$ & $47.05 \pm 2.76$ & $\mathrm{abc}$ \\
\hline & 8-11-14 & $1.61 \pm 0.48 b$ & $87.93 \pm 26.09 \mathrm{~d}$ & $21.38 \pm 5.72$ & $\mathrm{e}$ \\
\hline & $8-11-55$ & $2.25 \pm 0.12 b$ & $157.34 \pm 24.11 \mathrm{abc}$ & $37.86 \pm 5.86$ & bcde \\
\hline & $8-22-14$ & $1.80 \pm 0.17 b$ & $121.32 \pm 10.60 \mathrm{bcd}$ & $28.73 \pm 2.27$ & cde \\
\hline & $8-22-55$ & $2.38 \pm 0.75 b$ & $181.21 \pm 5.88 \mathrm{ab}$ & $43.13 \pm 1.55$ & bc \\
\hline & $8-33-14$ & $1.76 \pm 0.32 b$ & $150.44 \pm 9.71 \mathrm{abcd}$ & $35.51 \pm 2.42$ & bcde \\
\hline & $8-33-55$ & $2.59 \pm 0.53 b$ & $166.53 \pm 10.12 \mathrm{abc}$ & $39.54 \pm 2.58$ & bcd \\
\hline & $16-0-14$ & $10.01 \pm 0.35 \mathrm{a}$ & $193.50 \pm 30.97 \mathrm{ab}$ & $65.30 \pm 12.02$ & \\
\hline & $16-0-55$ & $12.34 \pm 3.54 \mathrm{a}$ & $195.60 \pm 31.03 \mathrm{a}$ & $63.44 \pm 10.41$ & $\mathrm{a}$ \\
\hline & $16-11-14$ & $2.31 \pm 0.60 b$ & $95.18 \pm 20.09 \mathrm{~cd}$ & $24.41 \pm 5.72$ & de \\
\hline & $16-11-55$ & $2.90 \pm 0.10 b$ & $178.09 \pm 17.75 \mathrm{ab}$ & $43.39 \pm 4.50$ & $\mathrm{bc}$ \\
\hline & $16-22-14$ & $0.63 \pm 0.14 b$ & $79.37 \pm 1.13 \mathrm{~d}$ & $17.69 \pm 0.07$ & $\mathrm{e}$ \\
\hline & $16-22-55$ & $2.87 \pm 1.13 b$ & $168.82 \pm 25.67 \mathrm{abc}$ & $39.45 \pm 3.18$ & bcde \\
\hline & $16-33-14$ & $1.29 \pm 0.71 b$ & $134.34 \pm 50.42 \mathrm{abcd}$ & $29.96 \pm 11.17$ & bcde \\
\hline & $16-33-55$ & $2.41 \pm 0.52 \mathrm{~b}$ & $157.41 \pm 31.69 \mathrm{abc}$ & $36.93 \pm 7.26$ & bcde \\
\hline
\end{tabular}

1. The numbers followed by the same letters within the group of same $\mathrm{NaCl}$ content are not significantly different.

2. The SLCs are coded according to their formula and homogenization pressure as $\operatorname{protein}(\%, \mathrm{w} / \mathrm{w})-$ fat $(\%, \mathrm{w} / \mathrm{w})$-pressure $(\mathrm{MPa})$.

3. $\mathrm{R}_{\max }$, maximum rate of sodium release; $\mathrm{C}_{\max }$, maximum concentration of released sodium; AUC, area under the curve of sodium release. 
Table 4.

Correlation coefficients between selected treatment variables and structural, textural, and sodium release properties of SLCs ${ }^{1}$.

\begin{tabular}{|c|c|c|c|c|c|c|c|c|c|c|}
\hline & \multirow{2}{*}{$\begin{array}{l}\mathrm{NaCl} \\
(\%)\end{array}$} & \multicolumn{4}{|c|}{ Treatment variables } & \multicolumn{5}{|c|}{ Measured variables } \\
\hline & & $\mathrm{P} \%{ }^{2}$ & $\mathrm{~W} \%$ & $\mathrm{~F} / \mathrm{S}$ & $\operatorname{Pr}$ & Porosity & $\mathrm{R}_{\max }$ & $\mathrm{C}_{\max }$ & AUC & Serum \\
\hline \multirow{2}{*}{ Porosity } & 1.5 & -0.08 & $0.51 *$ & $-0.58^{*}$ & -0.09 & & & & & \\
\hline & 3.5 & 0.00 & $0.75 * * *$ & $-0.84 * * *$ & -0.19 & & & & & \\
\hline \multirow{2}{*}{$\mathrm{R}_{\max }$} & 1.5 & 0.12 & $0.59 *$ & $-0.82 * * *$ & 0.03 & $0.55^{*}$ & & & & \\
\hline & 3.5 & 0.03 & $0.72 * * *$ & $-0.90 * * *$ & 0.12 & $0.76^{* * *}$ & & & & \\
\hline \multirow{2}{*}{$\mathrm{C}_{\max }$} & 1.5 & 0.05 & -0.27 & 0.12 & 0.11 & 0.24 & 0.37 & & & \\
\hline & 3.5 & 0.09 & 0.11 & -0.24 & $0.60 *$ & -0.02 & 0.48 & & & \\
\hline \multirow{2}{*}{ AUC } & 1.5 & 0.04 & 0.28 & -0.45 & 0.19 & 0.30 & $0.86^{* * *}$ & $0.62 *$ & & \\
\hline & 3.5 & 0.08 & 0.48 & $-0.66 * *$ & 0.37 & 0.42 & $0.84 * * *$ & $0.87 * * *$ & & \\
\hline \multirow{2}{*}{ Serum } & 1.5 & 0.10 & $0.71 * * *$ & $-0.87 * * *$ & -0.06 & $0.55^{*}$ & $0.96 * * *$ & 0.26 & $0.76 * * *$ & \\
\hline & 3.5 & -0.07 & $0.83 * * *$ & $-0.92 * * *$ & -0.09 & $0.85 * * *$ & $0.94 * * *$ & 0.28 & $0.72 * * *$ & \\
\hline \multirow{2}{*}{ Stress $_{\max }$} & 1.5 & $0.91 * * *$ & -0.34 & -0.14 & -0.01 & -0.10 & 0.14 & 0.23 & 0.09 & 0.15 \\
\hline & 3.5 & $0.78 * * *$ & -0.38 & -0.08 & 0.32 & -0.09 & 0.15 & 0.36 & 0.30 & -0.04 \\
\hline \multirow{2}{*}{ Strain $_{\max }$} & 1.5 & 0.23 & $0.61 *$ & $-0.77 * * *$ & -0.16 & 0.49 & $0.61 *$ & -0.21 & 0.29 & $0.65 * *$ \\
\hline & 3.5 & -0.15 & $0.61 *$ & $-0.64 * *$ & $-0.51 *$ & $0.74 * * *$ & $0.60 *$ & -0.29 & 0.19 & $0.76^{* * * *}$ \\
\hline
\end{tabular}

1. The numbers followed by one, two, and three asterisks indicate significant correlations for $\mathrm{P}<0.05,0.01$, and 0.005 , respectively.

2. $\mathrm{P} \%$ and $\mathrm{W} \%$, protein and water contents (w/w) in the SLCs, respectively; F/S, weight ratio of fat to solid content of the SLCs; Pr: homogenization pressure; $\mathrm{R}_{\max }$, maximum rate of sodium release; $\mathrm{C}_{\max }$, maximum concentration of released sodium; $\mathrm{AUC}$, area under the curve of sodium release; Serum, amount of liquid expelled from the sample during the compression test; Stress max $_{\text {, }}$ maximum stress measured during the compression test; Strain $_{\max }$, strain at the maximum stress. 
Table 5.

542 Correlation coefficients between selected treatment variables and structural, textural, and sodium release properties of fat-containing SLCs ${ }^{1}$.

\begin{tabular}{|c|c|c|c|c|c|c|c|c|c|c|}
\hline & \multirow{2}{*}{$\begin{array}{l}\mathrm{NaCl} \\
(\%)\end{array}$} & \multicolumn{4}{|c|}{ Treatment variables } & \multicolumn{5}{|c|}{ Measured variables } \\
\hline & & $\mathrm{P} / \mathrm{W}^{2}$ & $\mathrm{~F} \%$ & $\mathrm{~W} \%$ & $\operatorname{Pr}$ & $r_{g, f}$ & $\mathrm{R}_{\max }$ & $\mathrm{C}_{\max }$ & AUC & Serum \\
\hline \multirow[b]{2}{*}{$r_{g, f}$} & 1.5 & -0.21 & -0.26 & 0.28 & $-0.91 * * *$ & & & & & \\
\hline & 3.5 & -0.07 & -0.34 & 0.28 & $-0.86^{* * *}$ & & & & & \\
\hline \multirow{2}{*}{$\mathrm{R}_{\max }$} & 1.5 & 0.17 & 0.49 & -0.4 & 0.35 & -0.34 & & & & \\
\hline & 3.5 & -0.1 & -0.16 & 0.14 & $0.78 * * *$ & -0.52 & & & & \\
\hline \multirow{2}{*}{$\mathrm{C}_{\max }$} & 1.5 & 0.04 & $0.75 * * *$ & -0.57 & 0.15 & -0.41 & 0.35 & & & \\
\hline & 3.5 & -0.04 & 0.27 & -0.19 & $0.83 * * *$ & $-0.84 * * *$ & $0.74 * *$ & & & \\
\hline \multirow{2}{*}{ AUC } & 1.5 & -0.12 & $0.59 *$ & -0.35 & 0.44 & -0.44 & $0.89 * * *$ & 0.54 & & \\
\hline & 3.5 & -0.09 & 0.18 & -0.1 & $0.84 * * *$ & $-0.8 * * *$ & $0.8 * * *$ & $0.99 * * *$ & & \\
\hline \multirow{2}{*}{ Serum } & 1.5 & $-0.70 *$ & $-0.72 * *$ & $0.86 * * *$ & -0.41 & $0.68 *$ & -0.3 & -0.54 & -0.32 & \\
\hline & 3.5 & $-0.70^{*}$ & $-0.76 * * *$ & $0.89 * * *$ & -0.39 & $0.62 *$ & -0.14 & -0.5 & -0.43 & \\
\hline \multirow{2}{*}{ Stress $_{\max }$} & 1.5 & $0.80 * * *$ & 0.12 & -0.48 & 0.04 & -0.17 & -0.21 & -0.08 & -0.45 & -0.51 \\
\hline & 3.5 & $0.82 * * *$ & 0.41 & $-0.68^{*}$ & 0.35 & -0.31 & 0.18 & 0.17 & 0.13 & $-0.77 * * *$ \\
\hline \multirow{2}{*}{ Strain $_{\max }$} & 1.5 & 0.14 & -0.46 & 0.27 & -0.25 & 0.4 & 0.04 & -0.5 & -0.32 & 0.47 \\
\hline & 3.5 & -0.19 & -0.12 & 0.2 & $-0.82 * * *$ & $0.7^{*}$ & $-0.86^{* * *} *$ & $-0.88 * * *$ & $-0.89 * * *$ & 0.53 \\
\hline
\end{tabular}

1. The numbers followed by one, two, and three asterisks indicate significant correlations for $\mathrm{P}<0.05,0.01$, and 0.005 , respectively.

2. P/W, weight ratio of protein to water in the SLCs; F\% and W\%, fat and water contents (w/w) in the SLCs, respectively; Pr: homogenization pressure; $r_{g, f}$, gyration radius of the fat particles in the SLCs; $R_{\max }$, maximum rate of sodium release; $\mathrm{C}_{\max }$, maximum concentration of released sodium; AUC, area under the curve of sodium release; Serum, amount of liquid expelled from the sample during the compression test; Stress $_{\max }$, maximum stress measured during the compression test; $\operatorname{Strain}_{\max }$, strain at the maximum stress. 
Figure 1

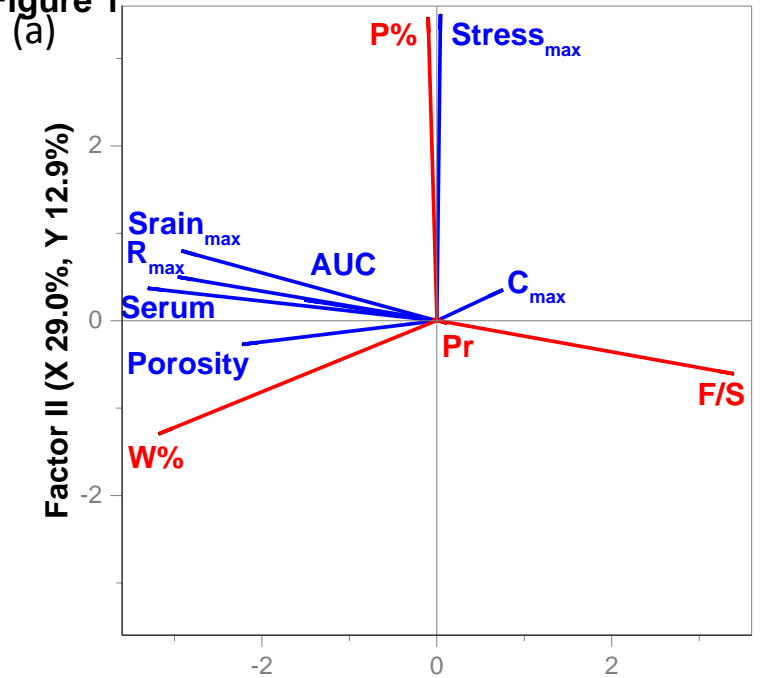

Factor I (X 44.6\%, Y 34.3\%)

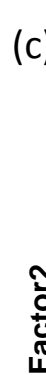

(C)

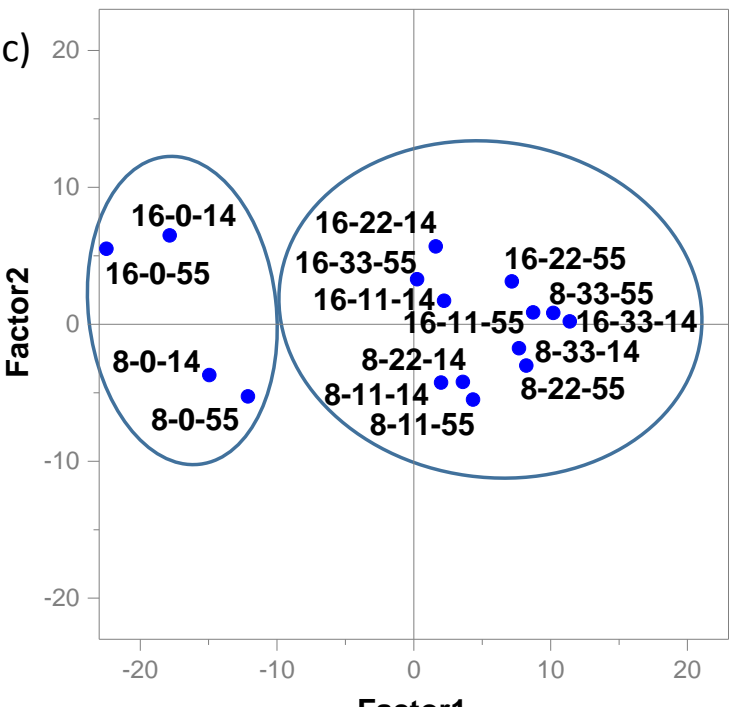

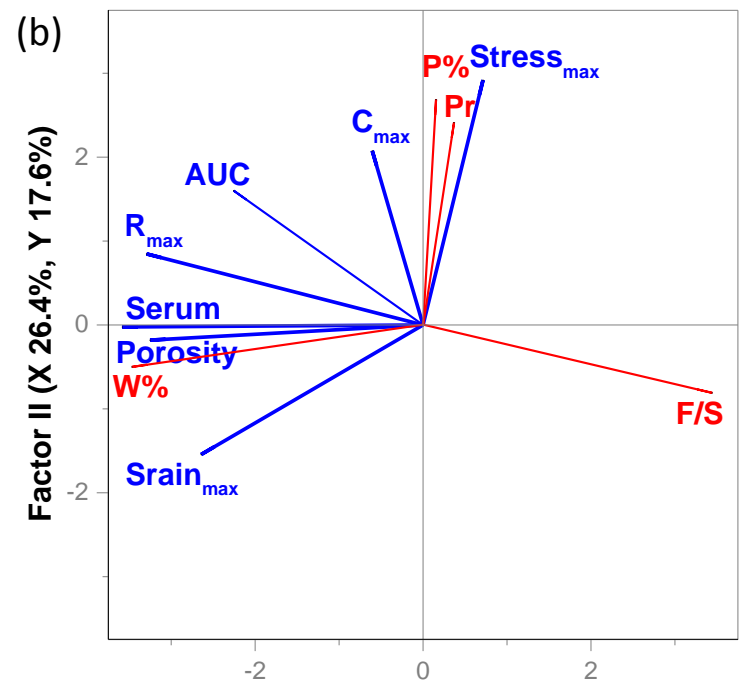

Factor I (X 45.6\%, Y 44.9\%)

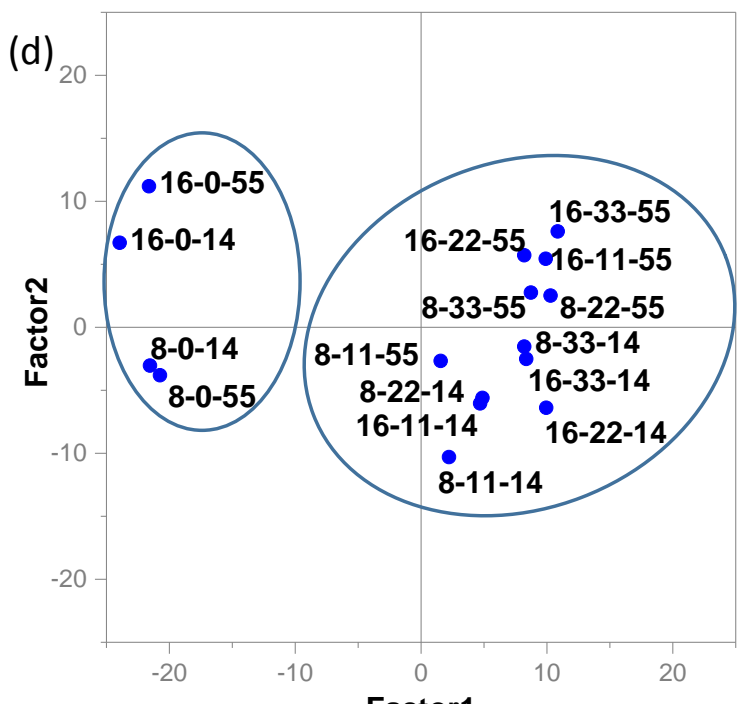

Factor1

Factor1 
Figure 2

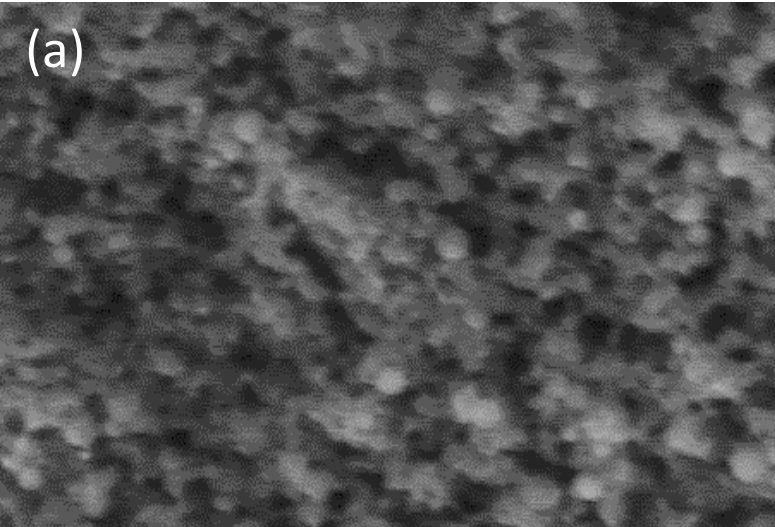

(c)

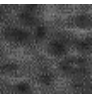

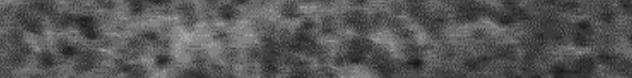

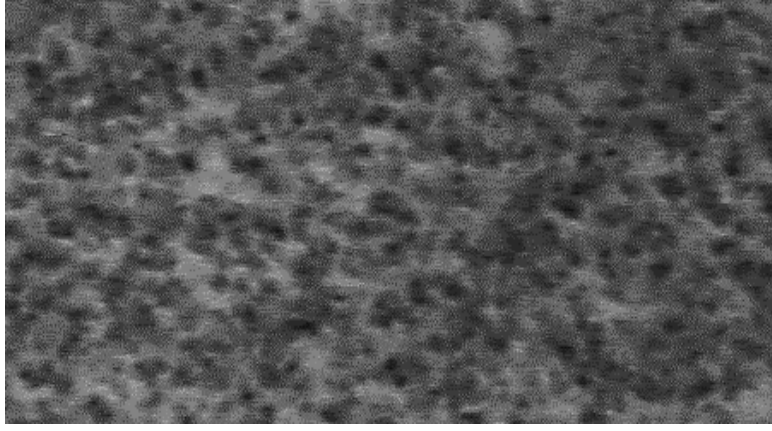

(d)

(b)

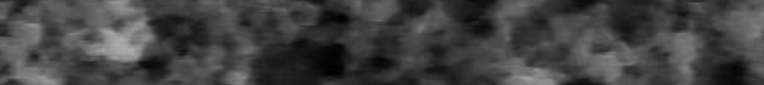

$20 \mu \mathrm{m}$

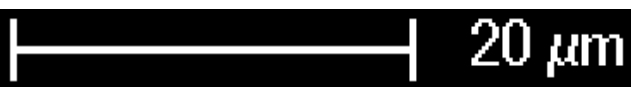


Figure 3
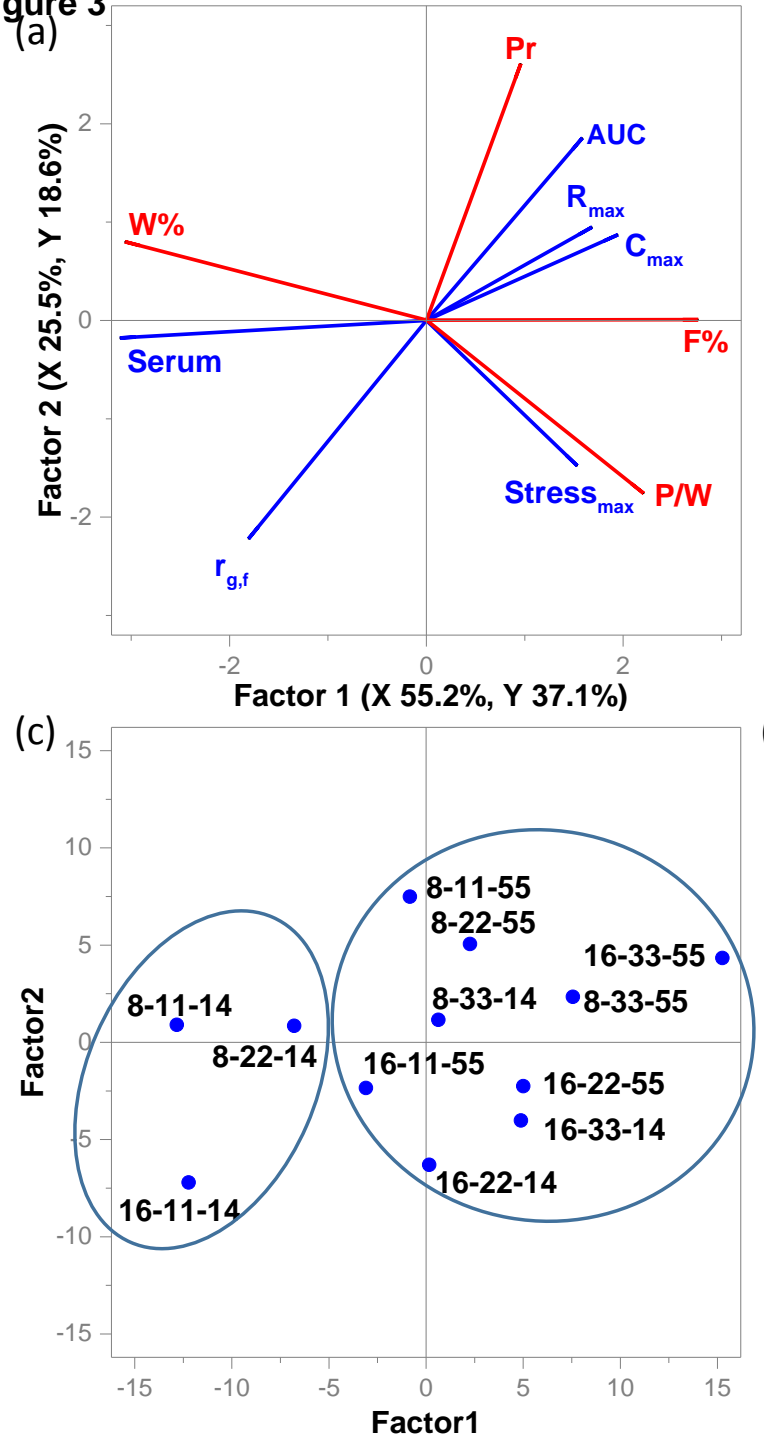

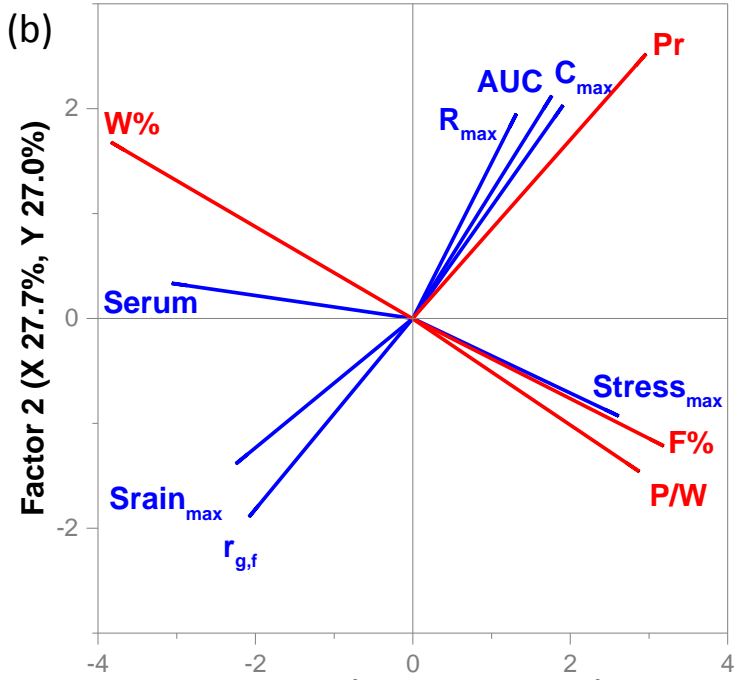

Factor 1 (X 51.4\% Y 48.7\%)

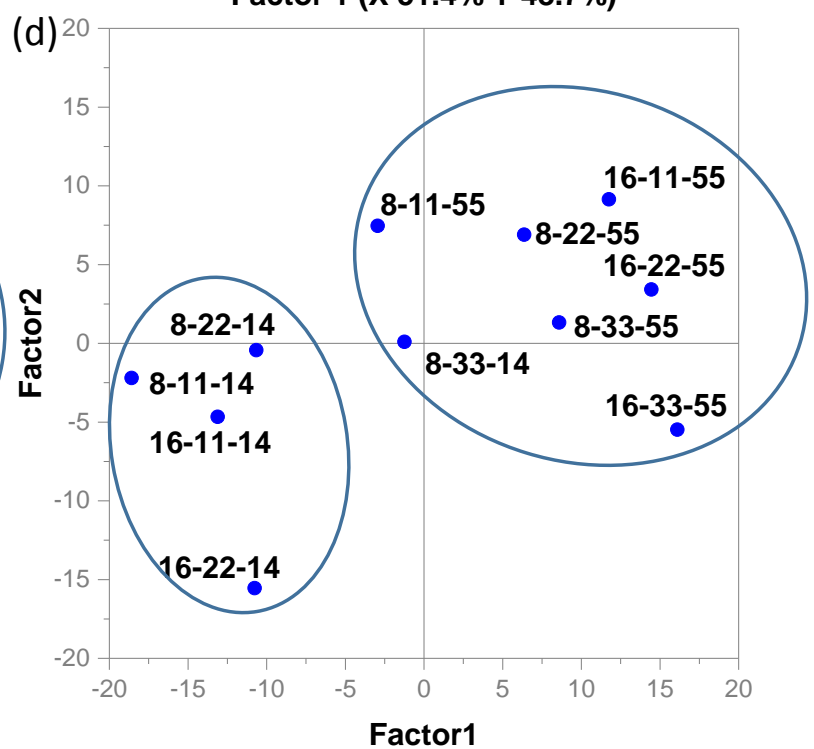




\section{Figures Captions}

2

3

4 Fig. 1.

$5 \quad$ Partial least square loading plots of $\mathrm{X}$ (red) and $\mathrm{Y}$ (blue) variables ( $\mathrm{a}$ and $\mathrm{b}$ ) and

6 corresponding Y score plots (c and d) of the SLCs with 1.5\% (a and c) and 3.5\% (b and d)

$7 \mathrm{NaCl}$. The SLCs are coded as protein(\%, w/w)-fat(\%, w/w)-pressure(MPa). P\% and W\%,

8 protein and water contents (w/w) in the SLCs, respectively; F/S, weight ratio of fat to solid

9 content of the SLCs; $\mathrm{Pr}$, homogenization pressure; $\mathrm{R}_{\max }$, maximum rate of sodium release;

$10 \mathrm{C}_{\max }$, maximum concentration of released sodium; AUC, area under the curve of sodium release; Serum, amount of liquid expelled from the sample during the compression test; Stress $_{\max }$, maximum stress measured during the compression test; $\operatorname{Strain}_{\max }$, strain at the maximum stress. The circles indicate the cluster analysis result.

\section{Fig. 2.}

Environmental scanning electron microcopy (ESEM) images of the cross-sections of SLCs with 1.5\% NaCl, 8-33-14 (a), 16-22-14 (b), 8-33-55 (c), and 16-22-55 (d). The SLCs are coded according to their formula and homogenization pressure as protein $(\%, w / w)-f a t(\%$, w/w)-pressure(MPa).

\section{Fig. 3.}

Partial least square loading plots of $X$ (red) and $Y$ (blue) variables (a and b) and corresponding Y score plots ( $\mathrm{c}$ and d) of the fat-containing SLCs with 1.5\% (a and c) and $3.5 \%$ (b and d) $\mathrm{NaCl}$. The SLCs are coded as protein $(\%, w / w)-f a t(\%, w / w)-p r e s s u r e(M P a)$. F\% and W\%, fat and water contents (w/w) in the SLCs, respectively; P/W, weight ratio of protein to water of the SLCs; $\mathrm{Pr}$, homogenization pressure; $r_{\mathrm{g}, \mathrm{f}}$, gyration radius of the fat particles in the SLCs; $R_{\max }$, maximum rate of sodium release; $\mathrm{C}_{\max }$, maximum concentration of released sodium; AUC, area under the curve of sodium release; Serum, amount of liquid expelled from the sample during the compression test; Stress max $_{\text {, maximum stress measured }}$ during the compression test; $\mathrm{Strain}_{\max }$, strain at the maximum stress. The circles indicate the cluster analysis result. 